Czetrwertyński S., Crisis of copyrights authority, „Ekonomia i Prawo. Economics and Law”, Polszakiewicz B., Boehlke J. (ed.), Vol. 15, No. 1/2016, pp. 47-57. DOI: http://dx.doi. org/10.12775/EiP.2016.004.

\title{
CRISIS OF COPYRIGHTS AUTHORITY
}

\author{
SUMMARY
}

This paper aims to explain crisis of authority of copyrights that is to prove incoherence between copyrights and a copying culture. In institutional meaning it is a conflict between formal and informal institutions. A formal institution is copyrights and informal one is set of standards and social behavior patterns which could be called a copying culture. Goal of the paper is demonstration of basic factors determining the afore-mentioned incoherence and reasons for its persistence. Performance of the afore-defined goal is associated with verification of two hypotheses. The first states that the crisis of the copyrights appeared because of Internet (which is a technical tool of a contemporary society). The second hypothesis states that enforcement of formal rights observance is hampered since it is not supported by informal institutions. The paper is divided into three main parts. The first part demonstrates an extent of crisis of copyrights and some probable reasons of the crisis are considered. The second part includes case studies related to enforcement of the copyrights which is aimed to explain reasons for persistence of the crisis. The third part focuses on alternative solutions of the problem which is conflict between formal and informal institutions. The paper is based on scientific reports on information goods non-market trade in Poland, Germany, USA and Sweden.

Keywords: copyright; copying culture; Internet

JEL Classification: A13; K11

Sławomir Czetwertyński, Wrocław University of Economics, Faculty of Economic Sciences, Department of Microeconomics and Institutional Economics, ul. Komandorska 118-120, 53-345 Wrocław, Poland, phone: +48 713680 918, e-mail: slawomir.czetwertynski@ue.wroc.pl. 


\section{INTRODUCTION}

In 80's of the twentieth century scientists paid attention to growing problem of erosion of copyrights authority in a society having growing access to information. The problem exploded along with development of technology of information goods copying which has become so common that finally the access has been granted to average consumers; in this way era of a copying culture has started. Following stage of the copyrights crisis was popularization of the Internet and domination of information goods digital recording technology. An effect of degradation of the copyrights authority is growing nonmarket trade of information goods, in particular produced by widely-considered entertainment and publishing industries. This phenomenon has become a symbol of open \& global information flow epoch.

An issue of the copyrights authority crisis can be based on assumption that they are not adjusted to the existing social situation. In other words, it is a sign of incoherence of formal and informal institutions, which has appeared along with popularization of information and communication technology. In this particular case a formal institution is copyrights, and informal one is what Joe Karaganis and Lennart Renkem call a copying culture ${ }^{1}$.

Generally, things are product of previous generations. Hence, they cannot meet valid needs of a particular society ${ }^{2}$. Institution of copyrights started to get formal shape in the time of Gutenberg press, and it full version was based on the grounds of Statute of Anne, that is in $1710^{3}$. Since then, this institution has become solid and binding law canon. In turn, the copy culture, which originates from previous stages of social development, got its present shape because of rapid growth of the technology - information revolution. As Manuel Castells wrote "society will not be understood or represented without its technical tools" 4 . In this context social institutions get a new meaning along with technical tools which a society has. This nexus might be a reason for crisis of copyrights which is an incoherent, still growing and informal copy culture.

Goal of this paper is determination of basic factors determining incoherence between the formal and informal institutions and reasons for its persis-

${ }^{1}$ J. Karaganis, L. Renkema, Copy Culture in the US and Germany, The American Assembly, New York 2013, p. 3.

${ }^{2}$ Cf. T. Veblen, Teoria klasy próżniaczej, Warszawskie wydawnictwo literackie Muza SA, Warszawa 2008, pp. 161-162.

3 P. Levinson, Nowe media, Wydawnictwo WAM, Kraków 2010, p. 128.

${ }^{4}$ M. Castells, Spoteczeństwo sieci, PWN, Warszawa 2007, p. 23. 
tence. Approaching this goal shall be associated with verification of two hypotheses. The first states that the crisis of the copyrights appeared because of the Internet which is a technical tool for a contemporary society. The second hypothesis states that enforcement of formal rights observance is hampered since it is not supported by informal institutions. In the first part of the paper there will be demonstrated extent of crisis of copyrights authority along with probable reasons. In the second part, considerations will be based on case studies concerning attempts of copyrights enforcement. The last part of the paper will be focused on short demonstration of alternative methods of liquidation of disadvantages arising from the crisis of copyrights authority.

\section{EXTENT AND REASONS OF THE COPYRIGHTS AUTHORITY CRISIS}

Copyrights belong to a wider family of intellectual copyrights. As the name shows itself, these are rights determining who products of intellect belong to; they are similar to proprietary rights which determine who physical things belong to. Considerations regarding the crisis of copyrights authority should be started from digression on socially approved ownership rights. Without any doubts ownership rights are rights which are socially accepted to a great extent. Both, legal sanctions but also common culture stigmatize persons breaching the ownership rights. The more accurately ownership (personally) is determined, the more people seem to believe it is wrong to seize it.

However, the same does not concern breach of copyrights. Hence, intellectual property rights seem for a society less significant compared to ownership rights to material things. It is proved by empirical researches conducted, among others, in Poland, Germany, Sweden or USA. In a report by Mirosław Filiciak, Justyna Hofmokla and Alek Tarkowski one can find data regarding opinions of interviewees on commonness of unauthorized copying of information goods via Internet. De facto it means breach of the copyrights. On the basis of analysis conducted by the authors four approaches were found. The most radical, called "everybody downloads" concerns just $8 \%$ of interviewees, however, it should be emphasized that after very deep analysis it turns out that more than a half of them think that large part of their colleagues do copy information goods from Internet in an unauthorized way. Other important statement is that prices of music and movies in Poland are so high that it is not strange Poles obtain them in an unauthorized way. Such an opinion was given by $76 \%$ of interviewees. In turn $26 \%$ of them think such an action means a theft which means that the remaining part of them either, 
have no opinion $(25 \%)$ or think it is not true (47\%). This last value, in connection with an opinion regarding high prices and conviction on popularity of such a practice, enable concluding that app. half of society does not think it is wrong or illegal. In turn, half of society is divided into two groups, one comprising those, who ignore this issue, and the second one which thinks it is illegal.

Similar tendencies are evidenced by examinations conducted by Karaganis and Renkem. Acc. to them half of USA inhabitants (46\%) and Germans (45\%) copied music, film or tv works without authorization despite the works in question were subject of copyrights ${ }^{5}$. Conduction of surveys in two countries showed that rate of this phenomenon is very similar although there have existed substantial geopolitical and cultural differences. Authors of the survey emphasize that information goods copying without a permit is widely accepted, in particular, in case it concerns a private use. Very high rate of copying persons are persons aged up to 30. It is app. 70\% examined persons in both of the countries ${ }^{6}$. Karaganis and Renkem show commonness of behaviors related to non-market trade of information goods which they call a copy culture. They define it as sharing or "free of charge downloading" of music, movies or tv productions.

Måns Svensson and Stefan Lersson during their surveys focused on social norms and intellectual property ask a direct question - do social norms among people aged 15-25 respond to legal regulations ${ }^{7}$ ? They say their study is survey in scope of cyber norms which are shaped in era of dynamic growth of information technology. From a report published by them it results that $75 \%$ of Swedish interviewees aged 15-25 do not think that illegality of copying is a reason to refrain from doing it ${ }^{8}$. It should be emphasized that in Sweden there has been developed a portal of illegal exchange of information goods The Pirate Bay, which has been considered a bastion of nonmarket trade subject of copyrights for years.

A sign of general disrespect of copyrights are also, commented by press, "leaks" of movies and tv serials. In 2015, from movies nominated to the prize awarded by the Film Academy, the most awaited titles were available in nonmarket trade long before their premiere on DVD. Source of the leak were so called promotional copies that is copies sent to critics and representatives

${ }^{5}$ J. Karaganis, L. Renkema, op. cit., p. 5.

${ }^{6}$ Ibidem, p. 30.

7 M. Svensson, S. Larsson, Social norms and intellectual property: online norms and the European legal development, Lund University, Lund 2009, p. 8.

${ }^{8}$ Ibidem, p. 59. 
of the industry who, it seems, should be sensitive to issue of the copyrights". A serious precedence took place in case of popular serial "Game of Thrones", four episodes (of fifth season) of which were available in a non-market trade before their premiere ${ }^{10}$. In turn, the last episode of the same season broke a record of illegal trade. During eight years it was downloaded by $1.5 \mathrm{M}$ persons. During a few days this value went up to $10 \mathrm{M}$. A single file was shared by nearly 225 thousand persons which means simultaneous copying at previously unknown scale ${ }^{11}$.

Even if main reason for non-market exchange of information goods are costs and availability, and generally, easiness of access to unauthorized content, there are no informal norms protecting from such a behavior. In turn, scale of the phenomenon does not enable effective "enforcement" of a society to stop this practice. Probable reasons for lack of these norms can be found in considerations of William R. Johnson, who, in half of 80's dealt with so called private copying. Acc. to Johnson's definition, private copying are actions consisting in exchange of content between persons, who belong to the nearest relatives that is family and colleagues. Johnson shows that, in a long perspective, they can be socially harmful ${ }^{12}$. His hypothesis seems to be very important in the era of Internet, which enables exchange of content between any persons. Private copying, which Johnson wrote about, had a local scale and was customized by its nature. Internet moved this practice into direction of anonymous exchange of global character. Private copying, taking place via traditional channels, is not perceived something negative. Practices in question comprise, among others, creation of music play lists or copying of books by students. Most of such behaviors belong to the category of permitted use. Usually, all these copies were of worse quality, in particular in 80's and 90's. The situation has changed due to popularization of digital technologies which make that copies are of great quality ${ }^{13}$. They are perfect substitute of authorized copies. De facto approaches have not changed but scale and

9 Torrentfreak.com, Leaked Oscar Movie Screeners Flood Torrent Sites, http://torrentfreak.com/ leaked-oscar-movie-screeners-flood-torrent-sites-150108 (18.06.2015).

${ }_{10}$ Torrentfreak.com, First Episodes of Game of Thrones Seasin 5 Leak Online, https://torrentfreak.com/first-episodes-of-game-of-thrones-season-5-leak-online-150412 (18.06.2015).

11 Torrentfreak.com, Game of Thrones Season Finale Breaks Piracy Records, https://torrentfreak. com/game-of-thrones-season-finale-breaks-piracy-record-150615 (18.06.2015).

${ }_{12}$ W.R. Johnson, The Economics of Copying, "Journal of Political Economy", Vol. 93, No. 1/1985, p. 172.

13 S.M. Besen, Private Copying, Reproduction Costs, and the Supply of Intellectual Property, The Rand Corporation, Santa Monica 1984; S.M. Besen, N.S. Kirby, Private Copying, Appropriability, and Optimal Copying Royalties, The Rand Corporation, Santa Monica 1987. 
extent of the phenomenon. This situation proves a problem of incoherence of formal and informal institutions. Simply, in era of local communication and domination of analog technologies this problem was relatively marginal. Presently, it grew up to a great level. David Price declares that nearly 23.8\% of data transfer in Internet in North America, Europa and Region of Asia and Pacific, is illegally copied ${ }^{14}$. In this area a BitTorrent network dominates. It is based on exchange between individual persons and in this field it is similar to private copying, however, not customized and characterized by global range.

\section{PERSISTENCE OF THE COPYRIGHTS AUTHORITY CRISIS}

As an effect of incoherence a solution of the problem has occurred but it requires share of a system of justice. It generates series of problems of organizational nature, not to say ethic issues. Attempt to prosecute all persons, who carry out unauthorized copying would be a certain failure because of great size of the phenomenon. In practice more than half of youths need have to be prosecuted. It is very problematic when it comes about BitTorrent users. Exchange of files via the network means simultaneous downloading and uploading of files ${ }^{15}$. Consequently, persons, who download files (which could be considered for personal use) are automatically persons breaching copyrights by dissemination of works, even if they disseminate them for non-commercial purposes. Enforcement authorities focus on large entities, which gain profits from the non-market trade. Serious successes were observed in case of portals storing computer files. The most famous example is MegaUpload website, closing of which in 2012 resulted in 17.9\% download traffic decrease (unauthorized information goods) from this kind of websites ${ }^{16}$. In the framework of charge, authorities of the Megaupload Ltd. were accused of contribution to losses in media industry equal to half billion USD and simultaneous generation of profits at USD $175 \mathrm{M}$ level ${ }^{17}$. Definitely worse results characterize operations of enforcement authorities against websites operating on the grounds of BitTorrent networks. For years, prosecution has been trying to block operations of the largest website related to BitTorrent that is The Pirate Bay.

14 D. Price, Sizing the piracy universe, NetNames, London 2013, p. 3.

15 P. Stryszowski, D. Scorpecci, Piracy of Digital Content, OECD, Paris 2009, p. 28.

16 D. Price, op. cit., p. 61.

17 Torrentfreak.com, MegaUoload Shut Down by The Feds, Founder Arrested, https://torrentfreak.com/megaupload-shut-down-120119 (20.06.2015). 
Since 2003 the website has had some legal problems but it still works despite them. Even fact of arresting of owners of the website and convicting them has not resulted in liquidation of the site. What is more, it still has a great share in unauthorized trade with information goods ${ }^{18}$. The website has been changing its Internet address many times and it was blocked many times, however, although authorities have made numerous attempts it has been still coming back. It is a clear example of helplessness of the system of justice. Despite actions of the system resulted in conviction of owners it is not able to stop operations of the website efficiently since life of the site has been maintained by Internet society. Another problem is number of sites supporting the BitTorrent network. At the beginning of 2015 in Poland a police operation took place. It resulted in closing of TnTTorenty.info ${ }^{19}$ but it failed to close such websites as Torrenty.org, HellTorrents.com or TorrentCity.pl and many others. Much better results characterize operations of Polish police against websites with movies and tv productions which operate on the basis of video stream. In 2015 nine Polish websites disappeared ${ }^{20}$. Still, it is insufficient number, especially that there works Anyfiles site which is great source of unauthorized information goods for a Polish Internet user. Summing up, one should pay attention to the fact that despite system of justice has been attempting to eliminate key sources of unauthorized trade with information goods, it is not able to overcome it. Socially supported initiatives are very resistant to such actions - as in case of The Pirate Bay since the Internet users take care for the site themselves. Since the copyrights (institution) does not match a social ethos it shows signs of false institution that is such one which is not supported by social norms ${ }^{21}$. It greatly hampers effective enforcing of it. It needs to be emphasized that there also exist problems in the field of interpretation of actions, in particular in a global scale. E.g. in Poland there has never been convicted any owner of a website operating on the grounds of BitTorrent files exchange system. A problem is existence of both of the institutions in a not-altered form which causes further conflicts.

18 Torrentfreak.com., The Pirate Bay Turns 10 Years Old: The History, http://torrentfreak.com/ the-pirate-bay-turns-10-years-old-the-history-130810 (20.06.2015).

19 A. Siennica, Seansik.tv i tnttorrent.info - kolejne portale z nielegalnymi filmami i serialami zamknięte, http://naekranie.pl/aktualnosci/seansik-tv-i-tnttorrent-info-kolejne-portale-z-nielegalnymi-filmami-i-serialami-zamkniete (20.06.2015).

${ }^{20}$ O. Rogalski, Policaj zamyka znane serwisy z nielegalnymi filmami i serialami! Wśród nich sq eKino.tv, iiTV.info i inne, http://naekranie.pl/aktualnosci/policja-zamyka-znane-serwisy-z-nielegalnymi-filmami-i-serialami-wsrod-nich-sa-ekino-tv-iitv-info-i-inne (20.06.2015).

${ }_{21}$ Cf. J. Godłów-Legiędź, Wspótczesna ekonomia. Ku nowemu paradygmatowi?, C.H. Beck, Warszawa 2010, p. 69. 


\section{LIQUIDATION OF EFFECTS ORIGINATING FROM THE COPYRIGHTS CRISIS}

A solution, different from enforcement of copyrights, is such application of copyrights to prevent unauthorized copying. It consists in (such) application of copyrights to enable free information goods distribution. This concept is called copyleft $t^{2}$. It is applied in form of varied types of licenses, among others - family of Common Public License GNU and Creative Commons. It applies institution of copyrights in order to reserve just certain copyrights, e.g. personal ones, with exemption of ownership rights ${ }^{23}$. This concept enables development and manufacture of information goods in a social way, e.g. by means of peer production. This innovation, to an institutional extent, is a significant deviation from main stream of copyrights. It shows social engagement into social production process characterized by non-commercial properties. In this case crisis of copyrights consisted in a need for institutional solution which would enable dissemination of social products (peer production products) under terms and conditions determined by authors, but in form of a free access. The copyleft concept is a picture of a need for freedom of intellectual values flow. Because of this reasons it has limited application in case of commercial designs since these require cash flows.

Other form of the copyrights crisis liquidation is innovation in the field of distribution solutions. It consists in a design of such a distribution system which makes consumers do not need any unauthorized trade. In practice it means protection of interest of information goods manufacturers and sellers by application of solutions based on online access, such as "cloud" that is cloud computing. Application of such solutions enables maintaining of control of content which consumers have an access to and which they must not copy. Such solutions are supported by offer flexibility and shortening of supplies chain by giving up physical carriers. Success of such a solution can be observed in case of Netflix service which dominated share in Internet in Northern America - app. 32\% of total Internet traffic. At the same time a substantial decrease in share of BitTorrent occurred - app. $5 \%{ }^{24}$. In regions,

${ }^{22}$ Y. Benkler, Bogactwo sieci. Jak produkcja spoteczna zmienia rynki i wolnośc, Wydawnictwa Akademickie i Profesjonalne, Warszawa 2008, p. 81.

${ }^{23}$ L. Rosen, Open Source Licensing. Software Freedom and Intellectual Property Law, Prentice Hall PTR; Upper Saddle River 2005, p. 69.

${ }^{24}$ Sandvine Incorporated ULC, Global Internet Phenomena Report: $2 H$ 2014, Sandvine Incorporated ULC, Ontario 2014, p. 6. 
where Netflix has smaller share, BitTorrent has greatly higher share as it is demonstrated in table 1.

Table 1. Rates of Internet traffic of Netflix and BitTorrent in the second half of 2014 (in \%)

\begin{tabular}{|c|c|c|}
\hline REGION & NETFLIX & BITTORRENT \\
\hline Northern America & 32.39 & 5.03 \\
\hline Southern America & 4.76 & 10.27 \\
\hline Europe & 2.97 & 14.40 \\
\hline Asia and Pacific & 0.00 & 31.58 \\
\hline Africa & 0.00 & 16.84 \\
\hline
\end{tabular}

Source: Own materials based on Sandvine Incorporated ULC, Global Internet Phenomena Report: 2H 2014, Sandvine Incorporated ULC, Ontario 2014, p. 6; 11; 15; 19; 21.

It should be explained that Netflix offers its services at $8.99 \mathrm{USD}^{25}$. For this price there is offered unlimited access to more than 7 thousand movies. Similar services are provided by Amazon.com company, which enables purchase of information goods stored in servers of the company. This solution enables purchase or borrowing of the latest items. Prices are definitely higher since they are similar to prices of traditional DVD. However, it is unquestionable that this solution is definitely more comfortable, among others because of the fact that purchase may be carried out anytime ${ }^{26}$. In both of the cases new distribution form constitutes a sort of alternative for the non-authorized trade. Implementation of reasonable price in connection with great access to information goods discourages acquiring them in other way. Obviously, the more persons have access to this type of content the lower temptation to unauthorized copying is. Moreover, keeping of a proper (native) copy by a seller means finally he/she still have regular control over it.

\section{CONCLUSIONS}

To conclude considerations it should be emphasized that crisis of the copyrights authority, reasons of which arise from incoherence of formal and informal institutions, and escalation of which occurred at the time of rap-

25 D. Grandoni, Netflix Raises Price By $\$ 1$ For New Customers, http://www.huffingtonpost. com/2014/05/09/netflix-price-increase_n_5294450.html (20.06.2015).

${ }_{26}$ Amazon.com, Amazon Instant Video, http://www.amazon.com/Instant-Video/b/ref=topnav_ storetab_atv?_encoding=UTF8\&node=2858778011 (20.06.2015). 
id expansion of information \& communication technologies, can be considered strictly negatively. Even if it could seem that the fact it is hard to overcome it, which is proved by problems regarding enforcement of copyrights, causes hampering of social order, in fact there takes place alteration of functions of copyrights and distribution of content subject of the rights. In particular, innovation in the field of distribution will efficiently liquidate effects of crisis of copyrights, promoting in this way rapid decrease of transfer within BitTorrent. Evolution of new forms of distribution has not been completed yet. Still unauthorized channels have advantage over authorized ones, in particular, in the global scale. Websites described previously are still unavailable in most of countries, however, unauthorized information goods trade is global and free from any limits.

Finally, new distribution ways and their globalization are supposed to take place, in particular, in context of low efficiency of copyrights enforcement. Today some symptoms are observed. E.g. works are entered into trade at the same time all over the world in order to avoid their flow via unofficial channels. This process has not been ended yet and it meets series of problems such as level of wealthiness in different countries which hampers effective price policy. Concluding, crisis of copyrights resulted in evolution of both, the institutions themselves and entities protected by them. New solutions should be treated in categories of institutional progress which leads to liquidation of incoherence between formal and informal institutions.

\section{BIBLIOGRAPHY}

Amazon.com, Amazon Instant Video, http://www.amazon.com/Instant-Video/b/ ref=topnav_storetab_atv?_encoding=UTF8\&node $=2858778011$ (20.06.2015).

Benkler Y., Bogactwo sieci. Jak produkcja spoteczna zmienia rynki $i$ wolność, Wydawnictwa Akademickie i Profesjonalne, Warszawa 2008.

Besen S.M., Kirby N.S., Private Copying, Appropriability, and Optimal Copying Royalties, The Rand Corporation, Santa Monica 1987.

Besen S.M., Private Copying, Reproduction Costs, and the Supply of Intellectual Property, The Rand Corporation, Santa Monica 1984.

Castells M., Spoteczeństwo sieci, PWN, Warszawa 2007.

Godłów-Legiędź J., Wspótczesna ekonomia. Ku nowemu paradygmatowi?, C.H. Beck, Warszawa 2010.

Grandoni D., Netflix Raises Price By $\$ 1$ For New Customers, http://www.huffingtonpost.com/2014/05/09/netflix-price-increase_n_5294450.html (20.06.2015).

Johnson W.R., The Economics of Copying, "Journal of Political Economy", Vol. 93, No. 1/1985, http://dx.doi.org/10.1086/261292. 
Karaganis J., Renkema L., Copy Culture in the US and Germany, The American Assembly, New York 2013.

Levinson P., Nowe media, Wydawnictwo WAM, Kraków 2010.

Price D., Sizing the piracy universe, NetNames, London 2013.

Rogalski O., Policaj zamyka znane serwisy z nielegalnymi filmami i serialami! Wśród nich sq eKino.tv, iiTV.info i inne, http://naekranie.p1/aktualnosci/policja-zamyka-znane-serwisy-z-nielegalnymi-filmami-i-serialami-wsrod-nich-sa-ekino-tv-iitv-info-i-inne (20.06.2015).

Rosen L., Open Source Licensing. Software Freedom and Intellectual Property Law, Prentice Hall PTR; Upper Saddle River 2005.

Sandvine Incorporated ULC, Global Internet Phenomena Report: 2 H 2014, Sandvine Incorporated ULC, Ontario 2014.

Siennica A., Seansik.tv i tnttorrent.info - kolejne portale z nielegalnymi filmami i serialami zamknięte, http://naekranie.pl/aktualnosci/seansik-tv-i-tnttorrent-info-kolejne-portale-z-nielegalnymi-filmami-i-serialami-zamkniete (20.06.2015).

Stryszowski P., Scorpecci D., Piracy of Digital Content, OECD, Paris 2009.

Svensson M., Larsson S., Social norms and intellectual property: online norms and the European legal development, Lund University, Lund 2009.

Torrentfreak.com, First Episodes of Game of Thrones Seasin 5 Leak Online, https://torrentfreak.com/first-episodes-of-game-of-thrones-season-5-leak-online-150412 (18.06.2015).

Torrentfreak.com, Game of Thrones Season Finale Breaks Piracy Records, https://torrentfreak.com/game-of-thrones-season-finale-breaks-piracy-record-150615 (18.06.2015).

Torrentfreak.com, Leaked Oscar Movie Screeners Flood Torrent Sites, http://torrentfreak. com/leaked-oscar-movie-screeners-flood-torrent-sites-150108 (18.06.2015).

Torrentfreak.com, MegaUoload Shut Down by The Feds, Founder Arrested, https://torrentfreak.com/megaupload-shut-down-120119 (20.06.2015).

Torrentfreak.com., The Pirate Bay Turns 10 Years Old: The History, http://torrentfreak. com/the-pirate-bay-turns-10-years-old-the-history-130810 (20.06.2015).

Veblen T., Teoria klasy próżiaczej, Warszawskie wydawnictwo literackie Muza SA, Warszawa 2008. 
